\title{
8 From Geographical Periphery to Conceptual Centre: The Travels of Ngagchang Shakya Zangpo and the Discovery of Hyolmo Identity
}

This chapter will explore and analyze dynamics of cultural production in a particular context, the Helambu valley (Nepal). The valley is home to the Hyolmo, a Nepalese minority of Tibetan origin, whose culture seems to have been shaped by the particular agency, within a sacred geography (Yolmo Gangra), of a specific class of cultural agents, namely the so-called reincarnated lamas and treasure discoverers. One of them, in particular, could be considered the cultural hero par excellence of the Hyolmo due to his role in establishing and maintaining long lasting relationships between distant power places, and to his spiritual charisma. His legacy still lives on among the people of Helambu, and his person is still revered as the great master who opened the outer, inner, and secret doors of the Yolmo Gangra. The role of treasure discoverers - or tertön (gter ston) ${ }^{1}$ - in the spread of Buddhism across the Himalayas is related to particular conceptions regarding the landscape and especially to the key-theme of the "hidden lands" or beyul (sbas yul). But the bonds linking a community to its territory are not simply an historical by-product. As in the case of the Hyolmo, the relationship between people, landscape, and memory is one of the main features of the identity-construction processes that constitute one of the most relevant elements of contemporary Nepalese politics.

1 Tibetan names and expressions are given in phonetic transcription, with a transliteration according to the Wylie system added in brackets after their first occurrence (or after a slash when entirely inside brackets). Longer expressions or work titles are given only in Wylie transliteration.

Note: This paper is based on fieldwork in the Kathmandu Valley and Helambu villages (Sindhupalchok district) conducted yearly since 2006 and intensified especially between April 2013 and October 2015, within the framework of the subproject "Buddhism between South Asia and Tibet - Negotiating Religious Boundaries in Doctrine and Practice" of the interdisciplinary research group "Negotiating Religion From a Transcultural Perspective" at the Cluster of Excellence "Asia and Europe in a Global Context," University of Heidelberg.

Ә Open Access. (C) 2019 Davide Torri, published by De Gruyter. (cc) BY-NC-ND This work is licensed under a Creative Commons Attribution-NonCommercial-NoDerivatives 4.0 International License.

https://doi.org/10.1515/9783110413083-008 


\subsection{The Ethnic Revival of Nepal and the Quest for Hyolmo Identity}

When asking "Who are the Hyolmo?" one is likely to receive quite a wide range of answers, replies and efforts at definition. Some among them are more refined than others; some are confusing or even unclear; but all of them have something in common: a stress on some key-concepts (or conceptual markers), pointing directly to a geographical or a cultural matrix, or more likely, to a combination of the two. As an example, some of the most common answers received during my fieldwork identified the Hyolmo as the people originally coming from Helambu valley (since now several of them are residing in Kathmandu valley) or, more accurately, the Buddhist people of the upper Helambu (since on the lower slopes there are also Hindu settlements). Even more specific were the answers linking the people with the place of Yolmo gangra (yol mo gangs $\mathrm{ra}$ ) or with the descendants and the legacy, of Shakya Zangpo and other famous Buddhist masters of the past.

These and other similar answers reflect a certain degree of discussion, research, study, and self-reflection. They include personal perceptions and social constructions, leading to enunciations in which individual and collective efforts at definition merge into articulated statements about identity, culture, location, language, religion, and position. A whole constellation of very slippery terms seems to constitute what people say about themselves, about their "essential" social being, their innermost "identity." This process, affecting not only the Hyolmo, has been sparked by recent events that have been characterizing the contemporary political history of Nepal for at least two decades, sending shockwaves through the rich and variegated social landscape of the Himalayan state. The Hyolmo were and still are, like many other communities, groups, and cultures, compelled to a renewed and sustained effort to assert their identity and distinctiveness vis-⿳亠丷⿵冂-vis the Nepali state and the other communities of the Nepalese civil society.

After two people's mass-movements (Nep. jana ändolan), a protracted Maoist insurgency, widespread political violence, repression, and the collapse of the Hindu monarchy, Nepal is now a republic, but still in a very uncertain, unpredictable, and unstable phase. The constitution-writing process, just completed and yet still far from its initial objectives, was hindered by power struggles between major and minor political actors and hotly debated issues which allow no easy solution to the current political stalemate. One of the most difficult issues to address is the one related to the transformation of Nepal into a federal state: a federalism that is intended to be shaped along ethnic (fault) 
lines. In this peculiar situation, every community is asking for proper representation in the parliament and in the public life, asking for a fair share of political and social power, which has been retained by Hindu upper castes (N. Bahun, Thakuri and Chhetri) that for so long have been strategically allied to the central and centralizing powers of the monarchy. For the very same reason, the whole ethnic revival is serving more or less vested political interests, and new political elites are emerging.

The ethnic revival of the Nepalese minorities is continuously displayed all over the country in a colorful blossoming of local festivals, performances of "traditional" songs and dances, and a rich production of literature, news services, and new media broadcasting in vernacular languages. In many cases, religion is also at the forefront of this revival; the fall of the monarchy was, after all, the fall of Hinduism as a state-religion, and it was greeted by many as the end of the "forced" sanskritization (Srinivas 1952) process, which was seen as inherent and intrinsic to the royal court "civilizational” process. Steadily, the Nepalese Hindu monarchy was incorporating all the non-Hindu groups into a caste/group hierarchy, finally codified in the Muluki Ain of the 1854 (see Höfer 1979): a social taxonomy, obviously oriented along Hindu lines of social organization, which was intended to provide the authorities with an ideal model of societal organization and thus making social positions immediately readable through the creation of five main groups (Pradhan 2011, 104):

1. tāgādhārī (Wearers of the Holy Thread): upper high castes.

2. namāsinyā matwāli (Non-enslavable Alcohol Drinkers): “Gurkha” groups (Magar, Gurung, etc., the so-called “martial tribes”).

3. māsinyā matwāli (Enslavable Alcohol Drinkers): Tamang, Chepang, Kumal, Sherpa, Thakali, Tharu, Gharti, etc.

4. pāni nacalnyā choi chițo hālnu naparnyā (Impure but touchable): lower occupational castes, Muslims, and Europeans.

5. pāni nacalnyā choi chițo hālnu parnyā: untouchables.

Most of the Buddhist groups inhabiting the High Himalayas were grouped into the category of enslavable alcohol drinkers, as the main criteria for the creation of the macro-groups were the Hindu notions of purity and pollution. A detailed analysis of this topic would surely lead us astray, and it is beyond the purposes and aims of this chapter. Nonetheless, it will be necessary to keep it in mind while addressing the more specific issue of the Hyolmo identity and the role Buddhism has in it. Dynamics affecting the Hyolmo community, in fact, are just a single part of a much more complex pattern affecting the Nepalese society as a whole. The issue of ethnic identity was already one of the key-points in Maoist discourses (Eck 2010, 45) too during the civil war. The Maoist leadership 
used it widely, and quite successfully, to mobilize large sectors of the society against the state under its flags; "the right of self-determination" was to become the norm of the "New Nepal" under construction. Moreover, the regional fronts of the guerrilla warfare were also ethnically configured in at least certain cases, like the Tharuwan Mukti Morcha, the Limbuwan Mukti Morcha, and so on, not to mention the organic link between the insurgency and the Magar of the Rolpa and Rukum areas, where the armed struggle actually started. ${ }^{2}$

In some ways, a discourse about ethnicity also predated the actual start of the civil war; in the late Eighties, it was already one of the key-words of the first People's Movement which brought the panchayat system to an end in $1990 .^{3}$ The relevance of the ethnicity issue is hard to overestimate; the idea of a new, republican, secular, federal state where all the social groups of Nepal have equal access to resources seems to rest on the very idea of a multi-cultural state in which all the different cultures are equally valued and represented. Paradoxically, the very same issue of ethnicity is today also one of the most dangerous features of Nepalese politics; the whole issue of federalism may prove too difficult to handle, and centrifugal movements could tear the social fabric apart. The years immediately following the civil war were in fact characterized by a very volatile political landscape, and insurrectional factions calling for a de facto secession of the Tarai plains from the rest of the country posed a very serious threat to the peace process, causing at the same time episodes of gory communal violence. To enforce or to pursue a project of ethnic federalism could open the way to balkanization and a grim future of disturbing conflicts. ${ }^{4}$

The current trends of ethnic fragmentation of the social and geographical landscape of Nepal are mirroring the political project of de-sanskritization of the State; the new Nepal, according to the common perception, should become a place of diversity. It should display all of the diversity, and differences, that the Hindu Monarchy tried for so long to subsume into a national identity centered on the "divine right" to rule of the king. Dominance of the high Hindu castes is equally rejected, and ethnic revival emphasizes antagonistic relations in terms of religions, languages and customs.

Why, some scholars query, do the people inhabiting the upper fringe of Nepal not participate collectively in this process under a single denomination? Hindu people from the south, for example, have been able to overcome,

2 Hutt (2004); Lawoti and Pahari (2010); Lecomte-Tilouine (2013).

3 Raeper and Hoftun (1992).

4 For a general discussion on the ethnic revival and inherent risks of conflicts, see Gellner, Pfaff-Czarnecka, and Whelpton (2008); Lawoti and Hangen (2013); Gellner, Hausner and Letizia (2016). 
to a certain extent, their differences and to project themselves in a very effective way in the political sphere under a single denomination (madhesi), and a unique party (Madhesi Janadhikari Forum). In terms of political activism, this seems more effective than extreme particularism, and in doing so, Madhesi have been able to successfully confront the hegemony of the high castes of the Hill region, although their approach was challenged, in the South, by Tharu and Dalit activism. In the upper part of Nepal, we also find several societies that share a common heritage: a historical link with the Tibetan plateau, spoken languages directly derived from Tibetan or even dialects of it, religious affiliation to Tibetan Buddhism, and so forth. These people from the mountains, who from an external viewpoint appear so clearly to share a common matrix, seem to fail to recognize it, pursuing specific identities by paying more attention to the differences between themselves than to their similarities. Variously defined by Tibetologists as "ethnic Tibetans," "Tibetanids," and the like, these groups seem to lack a common perception of their homogeneity. This homogeneity is reflected in the collective appellation, Bhotiya or Bhotia, given to them sometimes by other Nepalese citizens. However, even this external and collective appellation is problematic, its semantic boundaries being often blurred and vague, and the groups (e.g. Sherpa, Thakali, Tamang, Gurung, etc.) referred to by this term often do not feel represented by it.

Ramble tries to answer the question in these terms:

It was suggested above that the single most important component of national identity in Tibet was, and still is, Buddhism, but that the unity provided by the sense of a common religion was opposed to close attachment to a limited territory that found expression in cults of local gods. I believe that it is in the terms of the cult of gods of place that the identity of Nepal's Tibetanid enclaves in modern times is best understood. The people of these regions are certainly Buddhist (or Bonpo) at least in name, but the influence of these religions has generally not been strong enough that it could shift people's primary allegiance away from an identity determined by locality to one based on more abstract religious ideals. (Ramble 1997, 398)

In the end, this point seems to be one of the most relevant in order to analyze the contextual, essentially local, nature of the several and diverse Buddhist cultures of the Himalaya. Buddhism and local cults were, in fact, constantly woven into each other; while the dharma adapted to local conditions, slowly encroaching upon the terrain and often following the individual efforts, travels, and experiences of specific masters, vernacular influences were also shaping in reverse the contextualization of Buddhist ideas. The result appears often as the product of such a tension. That seems to be true at least for the Hyolmo of Nepal, whose history could well serve the purpose to highlight patterns of 
adaptation in a Himalayan valley. It is certainly true that place has a central role in identity-definition processes and the Hyolmo, as we will see, are not an exception to this. At the same time, this is true for every other group inhabiting in Nepal; identities are primarily local. In addition, to promote an idea of a greater identity, up to a real nationalism, you need a state, or at least the project of a state. In this sense, identity is not only a process, but also a project.

Shneiderman (2006), moreover, has poignantly remarked that Tibetologists have overlooked the whole concept of ethnicity, and this has led to simplistic assumptions about issues of identities of the many groups located on the southern fringes of the Tibetosphere:

In the anthropology of Nepal, it is accepted without question that in most cases the primary marker of social difference is in fact ethnic identification. The terminological absence of "ethnicity" as a key-category of analysis in Tibetan Studies stand out by contrast. Although the terms "ethnic Tibetan," "ethnically Tibetan" and "Tibetan ethnicity" are used frequently in Tibetan Studies, there is very little discussion of what these terms actually signify, or of ethnicity as a relational system. Religious and regional differentiation is written about, but little attention is paid to the question of ethnic identity within the overarching category "Tibetan." (Shneiderman 2006, 12)

Nepalese ethnicities, whatever their origin, must be understood and explained mainly in the wider frame of the Nepalese society. Ethnic names, in fact, were and are to be understood as intrinsically relational "labels" to negotiate social position vis-à-vis the state and other groups, in a process which is at the same time vertical (i.e. ethnicities produced/recognized by the state) and horizontal (ethnicities produced/recognized by interaction between neighboring groups), and subject to change over time. ${ }^{5}$ It is far more productive to try to see these groups as local societies defined by the continuous negotiation of spaces of economic, cultural, linguistic, and religious exchange with other local societies (de Sales 1991, 23). Historically, as it has been amply demonstrated (Levine 1987; de Sales 1993), identity is subject to changes and shifts resulting from adaptation to social conditions. ${ }^{6}$

Those who identify themselves today as Hyolmo constitute a sparse community of people linked to specific places of Nepalese geography, foremost among these, the Valley of Helambu/Hyolmo. Helambu valley lies North of Kathmandu Valley, below the Langtang Range, which separates it from the Kyirong area of Tibet (China). Their main religious affiliation is Nyingmapa

5 Lawoti and Hangen differentiate, in the Nepalese context, between "state-centric" and "people-centric" nationalism $(2013,7)$.

6 See, for example, Levine (1987); de Sales (1993). 
(rnying ma pa) Buddhism. Among the Hyolmo, Buddhism was mainly a nonmonastic tradition, based on village-temples and family lineages, in which the duties of the non-celibate householders and religious specialists (the lamas) were transmitted and inherited generation after generation from father to son. Hyolmo society appears to have been shaped by the diffusion of Buddhism in the region since ancient times, with the main settlements in the area apparently following the distribution and the progressive and expanding influence of the Lama families across the territory. Lama lineages, lama riba (bla ma rigs pa), were traditionally associated with jangter (byang gter) and nyingthik (snying thig) traditions, but nowadays members of the younger generations - often from non-lama lineages (Hyol. mangba riba) as well - seeking religious education also join the monastic orders of other schools.

In the social landscape of Nepal, Hyolmo as a distinct category seems to be a rather late addition; until the 1990s, in fact, they were known to outsiders as Helambu Sherpa, and they were using this ethnonym as part of their known given name. ${ }^{7}$ The category of Helambu Sherpa too was not around for a very long time; its use can be dated back to the beginning of the 1960's, since previously they were simply known, at least in ethnographic literature, as Lama people of Helambu. ${ }^{8}$ It seems that the adoption of the term "Helambu Sherpa" was a conscious effort at defining themselves as closely connected to the SoluKhumbu Sherpa, well-known for their role in guiding trekkers to the Everest region. The previous designation, "Lama People," was also an act of defining themselves in contrast to other groups inhabiting the lower parts of Helambu. In both cases, the ethnonym was a status marker pointing directly to a web of social relations with other groups: an essentially relational definition to position themselves in the social fabric of Nepal, confirming once more, that identity too is a process - against all essentialist views - and a social construction, shaped by internal and external forces, as already mentioned before. Whatever their name in the past, people inhabiting the Helambu valley understand that their ancestors were somehow related to Buddhist priests migrating from Tibet via Kyirong (skyid grong) and establishing religious buildings on land granted by Newari and Gorkha kings (as attested by royal documents about the guṭi land grants). These Buddhist temples and shrines became foci of social activities, and several of them became villages (Hyol. ghyang). The "colonization" of Helambu probably proceeded through diffusion of the descendants of the

7 In ethnographic literature, we find multiple names used for the Helambu people: Helambu Lamas, Helambu Sherpa, Yolmo Sherpa, and similar expressions. See, for example, Goldstein (1975); Bishop (1989, 1993).

8 See Clarke (1980c). 
Lamas families. As Robert Desjarlais wrote, "much less certain is how many others also migrated from Kyirong regions and, relatedly, to what degree the relocated Lama families formed marriage alliances with families already living in the Yolmo region" (Desjarlais, 2003: 7). For the purpose of the present paper, we will deal with the Hyolmo as a distinct social group, with well-defined social boundaries, but we should never forget that identities may not have the same degree of coherence and homogeneity that we would like them to have, and boundaries may have been more blurred that we may think.

After the first people's movement, the jana ândolan of 1990, the civil war (1994-2006), and the second jana āndolan of 2006, Nepalese society as a whole has been exposed to multiple forces, and the result is a polyphony of voices (a cacophony, according to some) each one reclaiming space, power, legitimization; the collapse of the Hindu Kingdom has awakened religious and ethnic revivals, with the creation of political (or highly politicized) spaces for discussion, negotiation and conflicts. The kaleidoscopic effect is a Nepal that is multifaceted as never before. In this context, as I said, the Hyolmo currently engage with other people and communities, trying to find their place, to assert their specific identity, and to gain visibility in the wider context of Nepalese society; it is a process of constant negotiation, which entails a huge effort to define themselves in order to be recognized by other groups.

\subsection{Of Travelling Masters and Other Wonders: From Padmasambhava and Milarepa in Hyolmo to Modern Settlements}

This process of identification and self-definition entails the production of a "shared memory" of sorts. In this respect, the figure of the Buddhist master, Ngagchang Shakya Zangpo (sngags 'chang shä kya bzang po), acquires a role of the utmost importance. He is, in fact, tied to events of an ancient and glorious past, directly relating to the first dissemination of Buddhism in Tibet, as well as to later events that provide the background for the creation of a Buddhist community in the Helambu valley of Nepal. Helambu itself - or yol mo as it is known in Tibetan sources - plays quite a central role too.

The early history of settlements in Helambu is shrouded in the mists of hagiographic stories and tales related to the spiritual adventures of Padmasambhava, who appears as the protagonist in many stories and whose presence and activities in the area are identified with a set of particular places. Geomorphic formations, which still testify to the villager, the wandering pilgrim, and the faithful devotee 
the miraculous feats of the great tantric master, are abundantly represented here. Footprints, stone artefacts, carvings and outstanding rock formations form a web of power-places scattered all around the slopes and ridges, inscribing the saint activities related to the praeparatio of the land for the sheltering of the dharma in times of danger and distress. Specific caves and clearings are associated with his resting, fighting, and meditation places, often overlooking the valley with its gorges, enshrined by the high cliffs and ridges of a crown of rocky and snowy peaks. In certain villages, Padmasambhava has a place also in narratives that constitute an integral part of the local shamanic lore and that are employed during rituals, testifying to the enduring impact that his figure has had in shaping the spiritual landscape of the Hyolmo. In these narratives, the master is often referred to only elliptically in Hyolmo as gyagar pandit (Tib. rgya gar gyi pandi ta), the Indian teacher, but also appears in many others tales as a local character, tied to the local shamans by a common, if fictive, kinship. Although there are no historical traces of the presence of Padmasambhava in the region apart from those attributed to him by folklore stories, if we accept that he was travelling to Samye (Bsam yas) through Kyirong, it is not impossible that he also sojourned in Helambu. The valley is, in fact, located just beside the main route linking Kathmandu valley to Tibet. Here, as in other places, narratives about Padmasambhava describe his activities as being concerned primarily with the domestication and taming of the landscape. The enigmatic Padmasambhava appears to be the exorcist and tamer par excellence in the pivotal events leading to the first dissemination of Buddhism in Tibet in the many narratives related to the taming of $l u(k l u)$ residing in lakes and controlling the waters (Dalton 2004), or in what is considered one of his most remarkable feats, the domestication of the riotous indigenous deities of Tibet hindering the construction of the first monastery at Samye (Dalton 2011, 66).

Another figure in the valley has a particular role in the religious history of the region and of Buddhism in particular; Milarepa seems to have been active in the area, according to some writings (especially in "the song of a yogi's joy") and oral lore. ${ }^{9}$ His meditation cave, Tagphug Senge Dzong (Stag phug seng ge rdzong), the "tiger cave lion fortress," dominates a steep passage in a particularly narrow point of the valley where the slopes become more similar to a vertical jungle and end in a rocky gorge, whitened by the tumultuous waters of the Melemchi Khola. As Quintman poignantly remembers:

9 However, Quintman (2014) deconstructs these sources and points to Tsangnyön Heruka as an active and creative agent in the process of geographical identification of relevant places appearing in Milarepa's biographies. Milarepa's Yolmo could therefore be the result of literary conflation of disparate materials culminating in the creation of a new sacred place. 
Few Tibetan figures have left an impression on the Himalayan landscape, both literary and geographic, as indelibly as Mi la ras pa (ca. 1028-1111), whose career as meditator and poet was punctuated by travel among mountain retreats across the borderlands of southern Tibet. Stories of his converting disciples, taming wild places, and subjugating local spirits carved out a terrain fertile for the spread of dharma, thereby defining the contours of a Buddhist topography on both sides of the Himalayan range. (Quintman 2008, 363-364)

These activities equate to landscaping, the process of "production and formulation of sacred space through a variety of means" (Quintman 2008, 370); textual and narrative traditions, in these cases, became active forces and effective means in defining perceptions and beliefs related to the environment. Narratives also accumulate like sediments upon each other. Instructed by his teacher Marpa, Milarepa seems to be bound to retrace the footsteps of Padmasambhava:

Likewise, for the local lord (gnas bdag) of Yol mo, the local protector (gnas srung) of Dpal 'bar, the lha btsan deities of Gangs Ti se, and so forth: the Mahācārya [Padmasambhava] bound them under oath. Then later on, they once again restored their oaths and vows of bodhicitta before Rje btsun [Mi la ras pa] himself, and having done so they were ordered to support the practice lineage. (Quintman 2008, 397)

These sequential subjugations seem to constitute a precondition of sorts for the creation of settlements at a later time (Childs 2012, 22), and became the ideal model for later rituals related to the land cleansing, blessing, and transformation (Schrempf 1994; Cantwell 2005; Gardner 2006). As a result, landscape is imbued with sacred meanings and values, recursively incorporated into textual sources, which are then inscribed or recognized in the physical geography through a system of symbolic signs that arose preternaturally. Many other caves and places in the valley are associated with other entities, like dẹkini (Tib. khandro $m a / m k h a$ ' 'gro $m a$ ), nāga (Tib. lu / klu) and even with King Gesar of Ling, a renowned epic hero in Tibetan literature.

When moving from religious narratives to other kind of sources, we find textual evidence produced by the state authorities of Kathmandu Valley referring to temples and villages of the Helambu valley. While this could be taken into account as a solid basis for a chronology, we must keep in mind that it could also demonstrate an a posteriori acknowledgement of the existence of settlements following the establishment of religious institutions. The real chronological data of at least some of these first settlements remains shrouded in a consistent haze of uncertainty and in the domain of oral local lore, where genealogical accuracy has been paired with an equally relevant genealogical creativity and selective amnesia. According to the pioneer studies of Clarke in the area, the oldest lama villages were founded by religious specialists and became religious foci, slowly emerging as village-temples belonging to this or that 
lineage through intermarriage with people already settled in or around the area. Regarding these people, much less is known. Expansion of the lama lineages then proceeded in several ways, mainly through fission (of the two sons of lama $\mathrm{X}$, one inherited the role of the father at village $\mathrm{X}$, while the other moved to another location and started the construction of a new shrine there), and apparently moving from North to South, and then Eastwards (see Clarke 1980a). This pattern of diffusion seems to start from the early sixteenth century, but further studies will have to clarify the exact nature of the spread of settlements tied to Buddhist lineages and religious establishments and settlements already existing in the area.

Apart from the local geography with all its religious and sacred connotations, the organic link with Tibetan Buddhism, which connected the Hyolmo with a web of power places that were located well beyond the boundaries of Helambu valley, is partially understandable as a result of migration and settling: a migration and settling process that has not yet ended, protracted over different time phases and spreading towards different directions. In the most recent years, in fact, the community has been affected by a new migration trend leading many people to desert Helambu in order to resettle in the outskirts of the Kathmandu Valley and particularly in the suburbs surrounding the Bodhnath stūpa area, like Chabahil, Jorpati and Tinchuli. ${ }^{10}$ At the same time, a consistent part of the Hyolmo youth is involved in an even larger diaspora towards Gulf Countries, South-East and East Asia, Europe, and North America, mainly for the purpose of seeking jobs. As noted by Childs:

The punctuated equilibrium model of migration, characterized by long periods of stability interrupted by brief periods of mobility, glosses over a fundamental, well-documented feature of human movements: although migrations can start as singular events, they typically evolve into protracted processes. (Childs 2012, 11)

The story of Hyolmo movements in the distant past can be diachronically mapped, to some extent, according to their "traditional" narratives (especially to the one related to Shakya Zangpo) so as to include some Tibetan places (Samye, Kyirong) and Bodhnath (Kathmandu valley) into an ideal map which could provide us with relevant insights about their history and identity. The

10 The disaster which struck Nepal in April 2015 massively affected the Sindhupalchok district; at least half of the known casualties were from this area and the seismic events severely damaged all the existing infrastructures, including road system, schools, health-check posts and the like. In the following months, the migration towards Kathmandu valley greatly increased, leaving many areas almost depopulated. 
relationship between the Hyolmo and the places they inhabit - the places they recognize as playing a role in their history - can certainly be defined as a "dynamic relationship"; it is, after all, a history made up of movements, both collective and individual, and self-reflecting activities on the role and importance of places in the past and for the future, through the present.

The story of the Hyolmo, as they formulate and understand it, is related to the travel of a renowned tantric master between two centers of power, Samye (Tibet) and the Kathmandu Valley, followed by a stop in a peripheral position (Helambu/Hyolmo). It is very interesting that, by being located in a middle position between two sacred centers, Helambu can be conceived of as a "double periphery"; the center of the ideal Hyolmo map is, in this case, peripheral to both the extremes. The definition of Helambu as a waystation on an ideal pilgrimage may appear paradoxical because it is exactly Helambu (or Hyolmo) with which most of the Hyolmo identify themselves, or which they identify as their ancestral and sacred land. This seeming-paradox can be explained by acknowledging that, despite being centered to that region, the Hyolmo narratives also express a continuous tension between the two poles - Samye as the origin place of their cultural hero, Ngagchang Shakya Zangpo, and Bodhnath, the place he was bound to renovate. Both places are firmly inscribed in the Buddhist sacred geography, and quite noteworthy is the fact that events related by the narrative framework we are taking into consideration are essentially tying Shakya Zangpo with powerful conceptual centers: the Tibetan kingdom of old, on the one hand, and one of the most important Buddhist holy places of modern and contemporary Nepal, on the other. As already noted by Clarke, the elaboration and the resulting fabric of Hyolmo social life is highly influenced by its location between Kathmandu and Tibet, by its geographical proximity to major trade and pilgrimage routes, and by its exposure to Buddhist literary tradition and to the power of the Nepalese state (Clarke 1980a, 320). To understand fully the ideas concerning Hyolmo culture and identity, one has to keep in mind these forces shaping it and making it unique. The relevance of the local dimension, so pivotal in the identity creation process, is determined by its external connections and shaped by them.

Shakya Zangpo was not the only one travelling in and out of the boundaries of Helambu; the land enclosure was blessed before, as we have seen, by Padmasambhava and Milarepa, as in a recursive process of confirmation and $\mathrm{r}$ enovation of its "sacred" nature. And the process is not obviously limited to the remote past; the other lama lineages, too, have stories of travelling and of exceptional, wondrous, or miraculous circumstances, as we will see, for example, in the case of Lama Rigdzin Nyima Senge (rig 'dzin nyi ma seng ge) (1687-1738), of the Tennyi Lingpa (bstan gnyis gling pa) lineage. 
The whole process has not ended; as the majority of the community shifted to the Kathmandu Valley, Helambu remained in the background and became firmly inscribed into their memories as a socio-religious focus, constantly referred to even in the urban environment. Its pilgrimage sites are nowadays advertised not only locally, but also tied to the general Buddhist revival attracting Nepalese and foreign visitors who travel along the ancient routes and sometimes even settle there.

This trend was partially brought to a grinding halt by the April 2015 earthquake, which severely affected the area. As in other parts of Sindhupalchok district, the Hyolmo villages were almost completely razed by the seismic events and the ensuing landslides; houses, shrines, roads, and schools were wiped away, together with the lives of many villagers. The reconstruction work proceeds at a very slow pace, and in the meantime, many settlements have witnessed a marked movement of villagers towards the Kathmandu Valley, which, despite also being affected by the earthquake and engulfed by refugees, still enables better access to services like schools and hospitals.

\subsection{A Sacred and Secret Land}

The notion of a sacred space of sorts, and the links between a community and the space they inhabit, has a pivotal role in many discourses about identity and ethnicity. In the case of the Hyolmo, the wondrous nature of Helambu Valley is related to the intrinsic powers inhabiting the landscape combined with its true essence according to the Buddhist worldview. The valley is in fact a beyul, one of the blessed "hidden lands," prepared as places of shelter and fortresses of the dharma in times of decadence, danger, and menace. ${ }^{11}$ As pointed out by Aris, "the earthly paradises awaiting the faithful in these valleys are described in terms which sublimate the real Himalayan landscape. Their identification as 'hidden lands' was accepted just as much by the groups living in their close vicinity as by the Tibetans who were mainly responsible for developing their cult” (Aris 1990, 97). In this way, local perceptions, ideas, and beliefs about the landscape were blended into a larger framework that transcends local boundaries and dimensions.

The ideas related to a beyul could be generally referred to an attitude toward the environment which incorporates diverse influences:

11 On the "hidden lands,” see Ehrhard (1994, 2013d); Diemberger (1997); Childs (1999). 
that environment incorporated both "pre-Buddhist" and "Buddhist" elements, There were mountains that were the homes of mountain gods, streams, and rivers where the $l u$ spirits dwelt, caves where holy lamas had meditated, marks that had been left in rocks by Guru Rimpoch'e or King Gesar, lakes whose patron spirits could aid lamas to divine karmic currents or tendrel, hidden valleys that had been opened by seers of the past as retreat-places for spiritual practice or escape from political turmoil. (Samuel 1993, 158)

It must be noted, at this point, that a general attitude toward landscape and environment as "animated" and inhabited by a host of non-human agents seems to be shared among several cultures of the Tibetan plateau and the Himalayan range (Torri 2015). The introduction of Buddhism does not heavily alter this conceptual framework, but rather it creates a new paradigm which incorporates, and hierarchically orders, all the various elements and entities according to an overarching Buddhist cosmological narrative. Mumford (1989) explains this process using the Bakthinian ideas of an essentially dialogic framework, in which different layers of meaning coexist simultaneously and interpenetrate, giving rise to a synthetic third one that encompasses both.

The resulting hierarchical order seems to derive, firstly, from a common religious capital rearranged according to a different economy of the sacred; local numina became part of the Buddhist conception of the samsāra and were thus subjected to conditioned processes. Secondly, this rearrangement was conceptually intended as a vertical opposition (Skt. laukika, "mundane," as obviously inferior to lokottara "supramundane") and a horizontal marginalization and subordination (from the center to the periphery according to an ideal mandala) (Ruegg 2008). ${ }^{12}$ This systematic hierarchization, which entails even an englobement du contraire (Dumont 1980: 239), appears to have been a very successful strategy for the incorporation and cooptation of diverse indigenous elements, providing a legitimate space for local numinous entities, from mountain gods to riverine spirits, ancestral deities, and the like (Dollfus 2003; Pommaret 2003; Steinmann 2003). In other words, it created a proper space for the negotiation of specific elements to be rearranged, reoriented, and assigned new values across trans-cultural and trans-religious boundaries.

It should be worth mentioning also that Buddhism, despite being the main feature of Hyolmo religious culture and, as such, also the cornerstone of their identity perception, is not the only significant feature. As in many other Himalayan societies, they have a substratum of a pre-Buddhist - or better, non-Buddhist religiosity or spiritual practice. This earlier religiosity has several points of contact with local forms known elsewhere by different names, which can still conveniently

12 See also Samuels' contribution to this volume. 
be defined as shamanism. The religious specialists of this older tradition are locally known as pombo or bombo, a term obviously related to the Tibetan bon. ${ }^{13}$ The bombo's main areas of activity are limited today to divination, fortune-telling, healing rituals, and seasonal offering to the clan-deities, but it cannot be excluded that, in the past, they were called to perform a wider number of rituals. A relevant part of the local folklore, in fact, is devoted to the stories of conflicts between lamas (often identified directly with Padmasambhava or Milarepa) and bombos who follow the old customs. Particular attention is given, in those stories, to the right to perform funeral rites, which, in one way or the other, the shaman is at some point always forced to relinquish. Even today, Hyolmo bombo, despite claiming formal adherence to Buddhism, still nurture an ambivalent and ambiguous stance towards it, keeping to their tradition, and transmitting their oral lore along continuing spiritual lineages. Mainly, they are to be found among the members of the mangba riba, the Hyolmo expression indicating non-lama families of Helambu. They retain also some special connections with specific power places, (e.g. the Gosainkund Lake) scattered across the valley and peaks of Helambu, and they have their own pilgrimage routes.

The Buddhist appropriation of the sacralized landscape - and not only in Helambu - seems to be encrypted in a series of narratives related to the "taming" of the land and its other-than-human agents (local deities and demons) or their vanquishing and defeat as performed by well-known characters such as Padmasambhava and Milarepa. In many cases, the diffusion of Buddhism as it appears in those narratives, is not the peaceful conversion of people upon hearing the Buddha's story, but the actual spiritual conquest of the physical terrain through exorcism and the taming and subduing of its other-than-human agents (see Huber 1999; Ramble 1999; Dalton 2004 and 2011). In the case of the beyul, then, once it has been properly prepared, the landscape becomes endowed with particular qualities:

Foremost is the palpable and visible presence of the body or teachings of Padmasambhava, the landscape being impregnated with his body marks, and relics, representing the master being widely on display. After the signs are recognized or the holy objects installed by a person with the necessary traits the place comes to possess a new spiritual quality, often visualized as a mandala with four entry points. The geographical dimensions of the place can vary to great extent, as already mentioned, and it can offer refuge to the followers of Padmasambhava in troublesome times. Having once been opened, it normally becomes the destination of pilgrims, who circumambulate either the place as a whole or the different objects in it, thereby coming into direct contact with the holy artifacts. (Ehrhard, 2013c, 224-225)

13 On the issue of Bön and shamanism see Bjerken (2004); Samuel (2013). 
The Hyolmo, and especially the oldest lama lineages, consider themselves the keepers and custodians of the holy places variously known in prophetic texts, guide books (Tib. lam yig), or inventory texts as Yolmo gangra ("screened by snowy peaks") or padma'i tshal ("the lotus grove”). To them, this is a blessed land, "an idealized and spiritualized landscape - the sky is like a bhavacakra with eight spokes, the earth like an eight petalled lotus" (Ehrhard 2013b, 123).

A manuscript fragment collected by Clarke in Helambu recites as follows:

I will tell you of the marks of distinction of the place we are living, Yolmo. Marpa, the disciple of Naropa of India, said to Mila Repa: "If you want to go to the land of Tibet, then you should go by the Nepal valley, and you must go to Grang-ra (t: gangs-ra) at Yolmo, and Ribo Pomba (t: ri-bo dpal-'bar) at Mangyul (Kyirong).” These two places were foretold in the Buddha's prophecies, and are two of the twenty-four holy places of the Tantras. They were foretold as Godavari (t: do-da'lba.ri) by the Pandit Gyandah Zu (t:nydza-ngha dza) as the most sacred of these twenty-four holy places. Padmasambhava of Udhiyana and Mila Repa, and Dorje Thudup's (t: mthu-stobs) master, rechung Dorje Dragpa (t: gratpa) and the Tertön dangso (t: grang-so), they all walked around Helambu and blessed it. Because of that, this land is different. (Clarke 1980a:350)

Contents of these prophetic guide-texts to the hidden land (variously titled yol mo gangs kyi ra ba'i lung byang snying gi, sbas pad ma tshal gyi lam yig, yol mo gangs kyi ra ba'i gnas yig, etc. ${ }^{14}$ ) give some indications as to where to locate the hidden valley, containing descriptions of its geography and its precise location according to Buddhist topographical terms. It is said, for example, to be North of Vajräsana, Northeast of Li (here intended as Kathmandu Valley), at the foot of Mangyul, at the throat of Buddha's devotee, at the western side of the mountain chief of the twelve territorial goddesses or two yojana to the east of Riwo Pelbar (ri bo dpal'bar) Mountain, South of the snow mountain resembling a victory banner, West of the yaksi snow queen, and so forth. They describe the valley as shaped like a lotus, eight-petaled, and rich in treasures and relics like a platter filled with jewels and precious stones, where the crops are rich and harvests abundant, where medicinal springs and streams flow incessantly. This is the land that was blessed and pacified by Padmasambhava for the sake of the dharma, disseminated with relics, guarded by vigilant spirits and deities, not to be defiled, contaminated or polluted. And it will be opened, it is said, at the right time by the right person (Dondrup 2010).

14 See Collected Biographies and Prophecies of the Byang Gter Tradition: Reproduced from MS. From the Library of Bla-ma Sengge of Yol-mo, edited by Sherab Gyaltsen and Lama Dawa (1983). 


\subsection{Shakya Zangpo, A Cultural Hero}

Generally speaking, the beyul are intrinsically related to the activities of a particular group of religious masters, the so-called tertön or treasure-discoverers. The valley of Helambu is tied in particular to two of them. The first is Rigzin Gödem Ngödrup Gyaltsen (1337-1408) (rig'dzin rgod ldem dngos grub rgyal mtshan), revealer of the jangter (byang gter) tradition, in which many of the prophecies related to Yolmo are contained, though it seems he never visited the place himself. The second is Ngagchang Shakya Zangpo, a follower of the jangter tradition, the renovator of Bodhnath and the discoverer and opener of the Yolmo gangra.

Who is Shakya Zangpo? Also known as Yolmowa tulku (yol mo ba sprul sku), tertön Shakya Zangpo is probably the single most important historical figure for the establishment of a modern religious and social community in Helambu, having immense prestige and still being referred to in relation to the primary features of Hyolmo culture in the contemporary ethnic revival. Not only, according to hagiographic narrations, did he open the secret doors of Yolmo beyul, thus starting the creation of a Buddhist community in Helambu, but he also found the abandoned and forgotten great stūpa of Bodhnath and renovated it. ${ }^{15}$ While Clarke, after examining genealogical lists initially proposed that Shakya Zangpo lived at the end of the $17^{\text {th }}$ century (Clarke 1980b), Ehrhard, after a careful analysis of various sources, sets the time of the life of Shakya Zangpo between the second half of the $15^{\text {th }}$ century and the first half of the $16^{\text {th }}$ (Ehrhard 2013b).

A biography of him collected by Clarke in Helambu recites as follows:

The father was a monkey and the mother was a demon. At that time the monkey stayed in one place, and the demon came, played and laughed with him, then they copulated and had many children. The eldest was called Na-chang Shakya Zangpo, the middle children were called Nagas, and the two youngest children were called Tangtsen (t: drang-btsan, "bearharmful earth-spirit”) and Shangtsen (t: zhang-btsan, "maternal uncle-harmful earth-spirit”). Na-chang Shakya Zangpo was born in Tibet, the snow land, where he stayed in Samye, and with a wife from Samye he moved to Palkun (t: dpal-kun), and from Palkun to Zongkar and from Zongkar to Zer-nang (t: dzar-nang), and then from Zer-nang to Yolmo Grangra, where he made a peaceful tour, converting the harmful spirits to protectors of religion. From the top of Yolmo he came down to Tsiri (t: tsis-ri, but Churi, brtsu-ri) and then became powerful. The population increased and he moved down to palchok, where he made a peaceful tour and converted the harmful spirits to protectors of religion. He taught Padmasambhava's religion, and then moved northwards to Nyagi. He made the area of Manikharka (a flat area immediately below Nyagi strewn with large rocks) peaceful, and converted harmful spirits to protectors of religion. (Clarke 1980a, 350)

15 On the stūpa of Bodhnath, see Ehrhard (1990). 
The wondrous nature of Shakya Zangpo is deliberately inspired by that of his archetypal model, the great master Padmasambhava. Shakya Zangpo is accorded a miraculous birth, a supernatural family, and a series of mystical adventures in order to pacify, exorcize, tame, and convert indigenous non-human entities inhabiting the country in order to transform them into dharmapāla (Tib. chökyong / chos skyong), the protectors of the Buddhist religion, or to confirm them in such a role, since we must suppose that Padmasambhava and Milarepa had engaged in similar activities, whose effects left supernatural marks in the landscape of Helambu. It is a well-known fact, after all, that such mundane entities are characterized by a flickering nature, and sometimes they need to be reminded to stay committed.

Shakya Zangpo's opening of the “outer, inner and secret" doors of the beyul, taming the local spirits, and building the first temple of the area, despite being so important for Helambu, were just the last of his feats, as mentioned in other sources. For example, another concise text adds some details:

The man's rigs (here "family lineage") is given as Shākya bzang-po, and his rus (here "caste") as drang srong (Skt. Brahmin), ${ }^{16}$ he being an emanation of Chos-blon Padma Gungbtsan. He is told to build a gompa in a land where the sky looks like the "wheel of worldly existence" (srid-pa'i 'khor-lo), and the land like the eight-petalled lotus. After receiving this prophecy, he comes by way of Ribu Pomba (Kyirong) to Kathmandu, where he repairs two stūpas, and then he opens the "outer, inner and secret" doors of Yolmo Gangra. (Ehrhard 2013b, 122)

The two stūpas mentioned in the texts are two of the most impressive Buddhist monuments of the Kathmandu Valley: Bodhnath and Svayambhunath. The aforementioned prophecy containing the story of the great stūpa of Bodhnath (or Jarung khashor [Bya rung kha shor] as it is called in Tibetan), which explains the circumstances of its construction, decline, and renovation, is very relevant to highlight the role of Shakya Zangpo, and his importance for the dharma in general and for the Hyolmo community in particular.

The text ${ }^{17}$ reporting the legend of the great stūpa starts with a religious assembly at Samye, the first monastery built in Tibet. At the gathering we find the three most important characters of those eventful times in which Buddhism gained a foothold in the country: the king Trisong Detsen (Khri srong lde btsan),

16 In this regard, it should be noted that according to recent studies the term drang srong could be, possibly, just a corruption of the toponym Drang-so, indicating thus not the "caste" but a geographical location, the place of birth of Shakya Zangpo. See Ehrhard (2013b).

17 This resume of the story of the great stūpa is based on the translation made by Dowman (1973). 
the abbot Sāntarakșita, and the tantric master Padmasambhava. Gathered together with them is the first nucleus of newly ordained monks and the supporters of the new religion. Giving a teaching to the assembly, Padmasambhava relates the story of the great stūpa, a story, astonishingly, which involves the very same people gathered there and listening.

Avalokiteśvara, committed to liberating from suffering all the sentient beings of the six realms, once wept two teardrops just from looking at the lower worlds. These two tears became the two daughters of the god Indra, the heavenly king, and were named Pūrṇa and Apūrṇa. Having stolen some flowers, Apūrna was reborn in the human world as a punishment, and more precisely, in the land of Nepal. She became known as Shamvara (Skt. Samvarī; Tib. demchok) or Yadzima, (Tib. bya rdzi ma) a poultry-woman, and she bore different sons from different low-caste men: a stable hand, a swineherd, a dog keeper, and a poultry-man. At some point in her life, she decided to use her savings to build a stūpa. Shamvara died during the fourth year of construction, but her sons kept working and completed if after three more years. When it was finished, each of the sons prayed and expressed his wish to be reborn in the land of snows and to help propagate the dharma there. One would be reincarnated as a king protector of religion; another as an abbot to organize the sangha, a third as a tantric yogin to protect the religion established by his two older brothers, and the fourth as a wise and religious minister in the very same court, in order to coordinate them. In the very same way, also the servant and even the animals at the construction site were able to obtain related rebirth. In this way, the servant of the four sons was reborn as Padma Gungtsen (gung btsan), another minister of King Trisong Detsen.

After this, Padmasambhava continues the explanation by stating all the benefits awaiting those who offer prayers at the great stūpa, and finally, he foretells a dark age of danger, when religious duties are forgotten, demons are enraged, and everything falls into ruins, including the stūpa. On hearing this, one of the disciples, Padma Gungtsen, abbot of Gos, asks: "O great Guru! Let me reborn to restore the great stupa when it is in ruin during the decadence and the corruption of that dark age." Willing to help him, the King Trisong Detsen asks Padmasambhava to be reborn as a servant of Padma Gungtsen's reincarnation: "but - he asks - how will I recognize him?" "He will be born in the year of the Hog in the highland of the province of Tsang to a family of Tāntrikas adept in the arts of magical transformation, and he will be called Pella Zangpo" was the answer. The terma, supposedly written down in the sacred script of the dākini by Yeshe Tsogyal, was recovered by Ngagchang Shakya Zangpo, who recovered it from its place of concealment at the monastery of Samye after receiving proper revelations through dreams. 
The identification of the tertön, Shakya Zangpo, with one of the first disciples of Padmasambhava, and previously, with one of the people engaged in the construction of the Bodhnath stūpa, grants him a special charisma and establishes, once and forever, a powerful link between the two external extremes of the Hyolmo religious landscape: the Samye monastery in Tibet at the time of the first dissemination of Buddhism, and Bodhnath in the Kathmandu Valley. Through his past life, he was a disciple of Padmasambhava at Samye and a minister of King Trisong Detsen, thus actively participating in the first dissemination of the dharma in Tibet. This placed him spatially and temporarily at the real center of Tibetan religious and political power (a duality expressed perhaps by his double role of disciple and minister). Meanwhile, in his present life, he is the pilgrim from Samye, on his way to restore the wonderful monument in the Kathmandu valley known in Tibet as mchod rten chen po bya rung kha shor (the great stūpa jarung khashor).

Because of the prophecy contained in the terma, he left Tibet and moved to the Kathmandu Valley (another center of political power) where he excavated the great stūpa, hidden - so the story goes - by the jungle and covered with earth. It is the very same stūpa that he helped to build in a previous life. After his intervention, the place regained its importance as a sacred space. Although it has obviously a longer history (built in the fifth or sixth century), it is with the rediscovery and the unearthing of the buried edifice that the stupa acquires relevance in Tibetan sources, and it became linked with the most important legendary and historical personalities of early Tibetan Buddhism (see for example, Ehrhard 1990, 7).

Other oral sources report that, after the renovation, Shakya Zangpo moved to the other side of the valley and participated in the renovation of Swayambhunath stūpa together with Tsangnyön (gtsang smyon) Heruka. When they met, they engaged in a display of magical powers. Tsangnyön Heruka made the clouds assemble over the places, and ordered them to thunder and hail. Seeing this, Shakya Zangpo, with the power of his mantras and mudrās, made the surrounding hills bend down to pay homage to $\mathrm{him}^{18}$; and so, it is said, it can be seen even today.

On his way back, Ngagchang Shakya Zangpo stopped near Kyirong, where he performed a spiritual retreat. At the end of the retreat he practiced divination and received instructions regarding the opening of the "hidden

18 The story of these magical contests was told to me by some of my informants, in Kathmandu, during the spring of 2008. According to Ehrhard (1991), it is a spurious tradition and the Shakya Zangpo involved in the renovation of the Swayambunath stūpa is not the Yolmo Tulku. 
land." According to popular stories collected in the region, from the top of Mount Ama Yangri, he threw an antelope horn (churi) in the air and followed it when it started to fly. He followed it into the hidden valley and stopped only when, upon touching the ground, the horn developed roots and became a juniper tree. On that site, he founded the Churi Ghyang (temple-village of the Antelope Horn). In front of the juniper, a small replica of the Bodhnath stuppa can be seen. According to many villagers, he was followed by twenty-one people (from the different clans) at this stage, and they founded the first seven villages in the area.

As reported by Ehrhard, while in Kyirong, Shakya Zangpo met with another famous tertön, Rigdzin Chogden Gonpo (rig 'dzin mchog ldan mgon po) of Lhodrak:

That treasure discoverer, [who is] an incarnation, having given to this master (i.e. sNgags-chang Sākya Bzang-po) many "introduction lists” (kha byang) of commonly known valleys, and one valley in particular, spoke to him: "Since now you possess the prophecies for opening and maintaining the 'gates of the hidden lands,' do that by all possible means." Uttering prayers for proper guidance and "truth-speaking” prayers [sNgags-chang Śākya Bzang-po] came into the hidden land Padma'i-tshal or Yol-mo gangs-ra, and founded the monastery Tsu-ti. (Ehrhard 2013d, 265)

The location of the first monastery ( $15^{\text {th }}$ century) is close to a meditation cave considered to be Shakya Zangpo's retreat place, and nearby it is still possible to see the juniper tree which supposedly blossomed from the antelope horn and a small stūpa which resembles a miniature version of the one at Bodhnath. Inside the monastery, a wooden phur ba made from the wood of the wondrous juniper is kept as a relic.

In a later document, we find the Nepalese royal confirmation of the land grant to the temple founded by Shakya Zangpo:

To Tembā Ghyān Jain Lāmā, to son of Nāmgā Ghyān Jain Lāmā, the descendant of Nājyāng Syāgpa Sāngpo, concerning Curi ghyāng and Duphopāko ghyāng. (The king says) I have recertified (the land title) that was given in the past, and the activities of the ghyāng as before. Namely the teaching of disciples, the carrying on of the activities of the gumbā, customs and all, by the carrying out of the daily and seasonal worshipping of Gorakhnāth, with due respect (to the laws of the land). By performing your own personal rituals, the counting of mani beads and meditating, in recognition of our sovereignity (sic), as in your previous instruction, (you are) to be the lord of the land. If any difficulties, large or small, occur, consult with the amāli of Listi, and act in accordance with his advice. Asaur, 1866, B.S., ${ }^{19} 4^{\text {th }}$ day, waning lunar fortnight, Sunday (Clarke 1980a, 45)

19 The date corresponds to September/October 1809. 
Among the lama lineages, the one claiming to originate from Shakya Zangpo is reputed to be one of higher status. Other lama lineages are to be found in the area, and their descendants also trace them to lama ancestors with the same kind of wondrous adventures. As an example, I will briefly report the origin story of the Tennyi Lingpa (bstan gnyis gling $p a$ ) lineage, the main lama lineage of the village of Tarkheghyang. This village was founded by lama Nyima Senge, from Kyirong.

A folk version of the story relates how the lama was called to the Kathmandu valley by a Newari king in order to stop an epidemic that was ravaging his capital and killing a large number of the population. With his powers, Nyima Senge stopped the epidemic and brought it under control. As a reward, the king gave him one hundred horses. On his way back to Kyirong, in Tibet, he had to stop when the horses refused to climb up the steep slopes of the Himalayan hills. Unable to proceed further with his reward, Nyima Lama complained to the king, who commuted the horses with the plot of land where they initially stopped. On that place, he founded a temple and then a village.

According to Clarke (1980a, 53), the epidemic in question could be the one recorded by Freyre during the year 1716 and lasting for five months, killing at least 20000 people. The historicity of these events seems to be confirmed by two copper plates which report land-grants to the village temples of Tarkeghyang, one of which recites as follows:

Sri Sri Jagajjaya Malla grants to Lama Nima Sring Ronge of Kero the land known as Tarkya, bounded to all four directions by land of the Royal House, totalling 66 ropani and in addition the 5 ropani of the dried out river bed. This is in return for the peace and prosperity returned consequent on the rituals performed by the Lama to ward off the epidemic in the Country. The land should be neither deserted nor mortgaged. As long as descendants or disciples of the Lama are living there, they should be available for any service to the king. 843 N.S. Chaitra, $1^{\text {st }}$ day, waning lunar fortnight. ${ }^{20}$ Witness Sri sri Rajendra Malla deva. (See Clarke 1980a, 52.)

What is interesting and very relevant in these documents is the link, which is made evident and unequivocally explicit, between local temples and the various governments of Nepal in the forms of land grants given by the Newari and Gorkha Kings, demonstrating the incorporation of these Buddhist enclaves into the religious framework of the Hindu Monarchy. Very relevant, in this regard, is the statement related to the "daily and seasonal worshipping of Gorakhnāth," protector god of the Shah royal house; the religious activities of the Buddhist temple of Churi Ghyang were intended to contribute to the field of ritual

20 The date corresponds to March/April 1723. 
activities for the benefit of the monarchy. This is probably the key for the interpretation of Hyolmo culture as a specifically local culture, where the influences deriving from Tibet and Nepal interfaced and merged into something peculiar to this area.

\subsection{Conclusions}

The valley of Helambu became a holy place, its nature transformed into something exceptional by the fact of its being a beyul, a "hidden valley," a place of refuge for religion in times of danger. As such, it is filled with relics from ancient times: shrines, sacred peaks, and religious focal points which make it, simultaneously, blessed and extremely auspicious to inhabit or to visit. Moreover, it is from this very particular religious essence that its importance for the creation of a local identity stems. In the case of the Hyolmo, the link between the people and the landscape depends on a specific definition of the inhabited and uninhabited spaces; this definition is grounded in religious perception, ideas, and beliefs about the landscape, conveyed through an equally specific set of narratives about the feats, travels, and practices of Buddhist masters from the past. It is from those actions that the place was sanctified, thus effectively becoming a power-center in itself and a real cornerstone in the process of identity making.

As we have seen, it is from the establishment of a network of shrines and temples managed by non-celibate lamas that the original settlements originated. And it is from the recognition of these settled lamas by the Kathmandu authorities that these settlements become more permanent, being allocated to the lama families together with the resources (namely, a plot of land and tenants) which are necessary to their maintenance and even expansion. At some point, the wandering lamas from Kyirong, due to recognition of Nepalese authorities, became something similar to a kind of landed gentry, receiving land grants as a reward, or in exchange for the fulfillment of the religious needs of the people, and for the celebration of rituals for the Royal Houses of the Kathmandu Valley. That is to say, the source of the charisma of the Lama families derives from a double source of authority: a religious one, from Tibet; a socio-economic one, from the kings of Nepal. Regarding Shakya Zangpo, it should be also noted that, beyond the establishment of a local community, he was also the founder of a religious lineage (Yolmo tulku / yol mo sprul sku) that transcended the specificity of Helambu. Its current spiritual leader, the tenth Yolmowa Tulku, now resides in Sikkim, having his seat at the Gomjang monastery near the city of Gangtok, thus holding a relevant position inside the wider framework of Nyingma tradition. 
The aforementioned narratives related to the sacred valley, which amply pervade the Hyolmo identity discourse, embed Shakya Zangpo in a dynamic geography and link him (and thus the Hyolmo) to crucial sites of Tibetan and Nepalese Buddhism. At the same time, Helambu Valley/Hyolmo became integrated into a wider system of transcultural (religious, political, economic) exchanges focusing on the spreading of Buddhism in the Himalayan region and the connection with "heroic" figures of the past such as those of Padmasambhava or Milarepa.

We can roughly identify two different groups of stories here: the first one is the terma (gter ma) literature, about the "hidden land" and also about Shakya Zangpo himself, like the Legend of The Great Stūpa which ends with the prophecy about Shakya Zangpo's re-discovery and renovation of the stūpa narrated by Padmasambhava to his disciples. A second group of narratives that focus on what happened after the renovation (i.e. Shakya Zangpo's travel back to Kiyrong and then back to Helambu): the histories related to the single lama lineages, the establishment of the first temples, and the foundation of villages, were mainly retold as part of the oral lore of the area, although they are sometimes supported by certain written documents. This part of the story is more local in its essence, providing Shakya Zangpo and other lamas with a retinue of followers (representing the Hyolmo clans) and pointing to the foundation of villages in Helambu. It contains also, as we have seen, narrations of magical events, and magical duels with other lamas or yogins.

A common pattern among several Himalayan communities engaged in the current process of ethnic revival seems to highlight at least some common areas which plays a pivotal role in the definition or assertion of a distinct identity: a strong bond with a geographical area identified and perceived as "ancestral," the specificity of cultural customs, a distinct language, and religion. The last census of Nepal (2011) offers a bewildering picture of the country's diversity with 126 caste/ethnic groups, 123 languages spoken as mother tongues and ten religions recognized by the state (Hinduism, Buddhism, Islam, Kirat, Christianity, Prakriti, Bon, Jainism, Baha'i and Sikhism). ${ }^{21}$

Others have fruitfully explored the role of the "frontier" as a contact zone between cultural areas (for example, the elaboration of the notion of Willem van Schendel's zomia [2002]) and its application to a theory on "ethnogenesis" based on "state-evasion" processes, which the very idea of refuge, shelter, or hidden valley seems to suggest; for example, see James C. Scott (2009) and the comments upon it, such as Journal of Global History vol. 5.2 (2010). Of particular

21 Data retrieved on the Nepal government website (http://cbs.gov.np/nada/index.php/cata $\log / 54)$ on October 23, 2017. 
importance is also Shneiderman's contribution, pointing to a key factor: notions of identity that "are grounded in a transnational economy of belonging" (Shneiderman 2010, 306). The perceptions related to one's own identity are multifaceted and grounded in multiple locations; in the case of the Hyolmo, this sounds astonishingly true. Fleeing or simply travelling away from the Tibetan plateau, the Hyolmo identity discourses acknowledge the spiritual source of some of their lineages as being located in the areas of Samye and Kyirong. Despite linking their innermost identity to the valley of Helambu, they are well aware of the legacy of Tibetan Buddhism, which has become increasingly important in the recent elaborations of ideas and notions about "Hyolmoness." At the same time, the field in which this "Hyolmo-ness" is being displayed is the Nepalese society, and it is in relation to Nepal politics about identity that their cultural heritage (language, religion, customs) has been, and still is being, scrutinized, selected, improved, and performed.

The emergence of a distinct identity, a process which we could call ethnogenesis, is the result of multiple historical processes entailing fission, fragmentation, hybridization, merging and juxtaposition, to name only a few. Some of these processes are external and vertical (e.g. State apparatuses organizing a census to map social structures and classifying the population according to a fixed scheme imposed from above), while others are horizontal (e.g. group pressure from neighboring communities competing for resources and status). Still other identity processes are internal (e.g. hegemony of certain groups in the "selecting” process of what constitute the proper "tradition" of the group; reactions of subaltern components of the very same society, etc.). We are should evaluate and assess the aforementioned processes only in a retrospective way if, conditio sine qua non, they have led to the historical establishment of a group distinctiveness (Rodseth 2005, 88).

This distinctiveness, if properly analyzed and deconstructed, reveals itself for what it is: a reordering process allocating similarities and differences in order to coexist in a wider system of social relations. If we consider the whole process, which I will call from now on the "invention" of Hyolmo identity, we will see that it is grounded in three conceptions. A) "Invention," in the etymological sense of the word, comes from the Latin invenio, and means "to find," "to discover," or "to come upon." In this vein, a prolonged and sustained dialogue has been ongoing for several years now between several groups who recognize themselves as Hyolmo. Moreover, several people are engaged in studies regarding historical documents and oral traditions pertaining to lineages, villages, language, stories, and so on. Also, a repertoire of songs and dances has been more or less formalized and it is actually displayed on occasions of public gathering. B) Drawing on Anderson and his work on "imagined communities" (2016), we can 
explore "invention" as "imagination." Among the Hyolmo, communities produce shared memories or histories as textual (narrative) models of/for themselves, envisaging a place and a context for that community in the socio-political framework of Nepalese society. C) Invention also entails an active "selection" process of what is distinct, what is similar, what is different, and so on between a postulated "us" and external "others."

As mentioned before, the whole process was set in motion by the political events and the "ethnic revival upsurge" of the 1990s and the following civil war. Moreover it was accelerated by the process of urbanization and migration from Helambu valley to Kathmandu, in the first place, and secondarily from Kathmandu to various destination abroad (e.g. India, Gulf Countries, Middle East Korea, Europe, North America). The process was and still is more or less consciously driven by urban, literate, Buddhist, relatively wealthy elites that, from the Kathmandu valley, engage in discussion with various members of the Hyolmo communities, with local and national politicians, and with social activists belonging to other groups. Among the most important interlocutors, we find the Nepal Federation of Indigenous Nationalities (NEFIN), an umbrella organization grouping at least 56 different ethnic groups, with which the Hyolmo Society (Hyolmo Sangh) is affiliated. The NEFIN works as a very centralized network, able to mobilize a relevant part of the population in order to exert political pressure on the Government on certain issues related to inclusiveness, secularism, education, and other critical areas where minorities feel they were discriminated against in the past. The history of the Hyolmo Sangh and its wing organizations can be traced back to the early Nineties when a small group of Hyolmo settled in the Kathmandu valley and decided to start gathering regularly to keep alive the sense of a social group with a common origin in the new urban environment.

Before being political, the necessity was religious. In the city, the Hyolmo were detached from their main religious institution, the village-temple, and their lamas were confined to perform their rituals in their private houses. They did not feel at home when attending performances at other religious institutions of the Kathmandu valley, manned mainly by the diasporic Tibetan community, neither did they find a place to congregate and celebrate in the nearby Sherpa Gompa. It must be remembered that, in those years, the Hyolmo were more or less officially known as Helambu Sherpa, but the Sherpa Gompa functioned exclusively as the religious and social focus of the Solu Khumbu Sherpa. A first solution was found in the premises of the Chabahil stūpa, under the guidance of Palsang Lama Hyolmo. The small building attached to the stūpa was renamed Ngagchang Shakya Zangpo Gompa and became the first headquarters for the urbanized Hyolmo. In the political turmoil of the Nineties, several voices were raised about a multicultural, secular Nepal. The Hyolmo joined 
in and started asserting themselves as a distinct janajāti ādivāsī group, mainly through the inspiration of Kancha Lama Hyolmo, a politician originally from the village of Sermathang.

After a few years, as the community living in the suburbs surrounding the Bodhnath stūpa in the Kathmandu valley increased in size, a new organization was founded, the Hyolmo Social Service Centre (Hyolmo Samaj Sewa Kendra), and a plot of land was acquired in the area of Tinchuli after a campaign of voluntary donations. On that plot of land, the Hyolmo Gompa was finally built, with the efforts, donations, and annual membership fees of many sponsors belonging to the community. The Hyolmo Gompa and its premises constitute the new focus of the diasporic community, in religious and social terms, and it is used for rituals and for lay gatherings as well. It also embodies an ideal new center from which to assert and display a Hyolmo identity. In this regard, the Gompa and its premises can be considered a repositoire, a laboratory, and a cornerstone for the definition of a shared heritage; it is a space for religious, social, and ideological production where Hyolmo culture is elaborated, codified, adapted, show-cased, and experienced.

The Hyolmo identity had to be rediscovered by its proponents; but to rediscover is also to re-member, bringing back together what was dis-membered (Bhabha 1994, 63), sparse, diffused. The whole process of abandoning the Helambu Valley, deserting ancestral villages and moving away from Hyolmo's distinct places paradoxically sparked a "revival” of "original” Hyolmo culture in the new web of social relations in the Kathmandu valley, mainly due to the political environment between the two people's movements, ultimately leading to the demise of the Hindu Monarchy. At the very same time, this whole process triggered a shift in the Hyolmo self-perception. In the past, identity, as testified by existing ethnographic literature about several Himalayan communities, was essentially centered on the local dimension, mainly because people were not often dislocated, and if dislocated, they were still socially and ritually attached to their ancestral places. Today, the Hyolmo look back at Helambu as the "original" place from where their culture originated and is deeply rooted; however, nowadays the community has been invested in a mass migration to the Kathmandu valley. It is true that a relevant part of the population still inhabits the ancestral villages, but one cannot avoid noticing the sheer number of locked houses and deserted temples, the abandoned fields and solitary paths, even more so after the devastating effects of the earthquake. Employment opportunities, education, and health facilities have drawn old and young people away from Helambu and into the new urban settings of an ever-growing Kathmandu. If anything, the community is not local anymore, and this is the reason why, recently, the Hyolmo Samaj Sewa Kendra added the word "Nepal" 
to its official name. The transformation of the Helambu Sherpa - a local, imprecisely defined society - into the Nepalese Hyolmo - a national indigenous group (janajāti ādivāsī) officially recognized by state apparatuses - is complete. In this sense, the construction of the Hyolmo Gompa answered two different issues. First, it tangibly counteracted the social dispersion intrinsically tied to the relocation to an urban environment and the physical deprivation of a proper socialized space (i.e. the Helambu valley, the beyul, the villages and the communities, the temples) with its historical background and its religious value. Second, it recreated and refocused the community that moved to the Kathmandu Valley by repeating, or perhaps imitating, the actions of the first lama settlers of Helambu: the building of a temple.

The first place where the Hyolmo gathered in the premises of the Chabahil stūpa was renamed after the Hyolmo cultural hero and opener of the beyul, Shakya Zangpo. Ngagchang Shakya Zangpo stories constitute the center of a web of entangled narratives that revolve around a specific central place, the beyul, with deep ramifications into different directions and times, namely the connections with sacred chronotopes located elsewhere, like Samye and Bodhnath: The history of Helambu, both social and religious, cannot be disentangled from this powerful figure, connected to the remote past of myth, to events that happened in Tibet, to the establishment of a community in Nepal in historical times, up to the quest for a specific identity in present-day Nepal. These narratives provide the Hyolmo, as a group, with an ideal, well-defined and legitimate social place from where they can position themselves vis-à-vis the other Nepalese communities with which they share time and space, memory, and history.

\section{References}

Anderson, Benedict. 2016. Imagined Communities: Reflections on the origin and spread of nationalism. London/New York: Verso Books.

Aris, Michael. 1990. Man and Nature in the Buddhist Himalayas. Himalayan Environment and Culture. New Delhi: Indian Institute of Advanced Study.

Bhabha, Homi K. 1994. The Location of Culture. London: Routledge.

Bishop, Naomi Hawes. 1989. "From Zomo to Yak: Change in a Sherpa village." Human Ecology 17.2:177-204.

Bishop, Naomi Hawes. 1993. "Circular Migration and Families: A Yolmo Sherpa Example." Comparative Studies of South Asia, Africa and the Middle East 13.1-2:59-66.

Bjerken, Zeff. 2004. "Exorcising the Illusion of Bon 'Shamans': A Critical Genealogy of Shamanism in Tibetan Religions." Revue d'études tibétaines 6:4-59.

Cantwell, Cathy. 2005. "The Earth Ritual: Subjugation and Transformation of the Environment.” Revue d'études tibétaines 7:4-21. 
Childs, Geoff. 1999. "Refuge and Revitalization: Hidden Himalayan Sanctuaries (Sbas-yul) and the Preservation of Tibet's Imperial Lineage.” Acta Orientalia 60:126-158.

Childs, Geoff. 2012. "Trans-Himalayan Migrations as Processes, Not Events: Towards as Theoretical Framework." In Origins and Migrations in the Extended Eastern Himalayas, edited by T. Huber and S. Blackburn,11-29. Leiden: Brill.

Clarke, Graham. E. 1980a. "The Temple and Kinship amongst a Buddhist People of the Himalaya." Ph.D. thesis, University of Oxford, Oxford.

Clarke, Graham. 1980b. “A Helambu History.” Journal of the Nepal Research Centre 4:1-38.

Clarke, Graham. 1980c. "Lama and Tamang in Yolmo." In Tibetan Studies in honor of Hugh Richardson, edited by Michael Aris and Aung San Suu Kyi, 79-86. Warminster: Aris and Phillips.

Dalton, Jacob Paul. 2004. "The Early Development of the Padmasambhava Legend in Tibet: a Study of IOL Tib J 644 and Pelliot tibetain 307." Journal of the American Oriental Society 124.4:759-772.

Dalton, Jacob Paul. 2011. The Taming of the Demons: Violence and Liberation in Tibetan Buddhism. New Haven/London: Yale University Press.

de Sales, Anne. 1991. Je suis né de vos jeux de tambours: la religion chamanique des Magar du nord. Recherches sur la Haute Asie, 11. Nanterre: Société d'ethnologie.

de Sales, Anne. 1993. "When the Miners Came to Light: The Chantel of Dhaulagiri." In Nepal Past and Present: Proceedings of the France-German Conference, Arc-et-Senans, June 1990, edited by Gerard Toffin, 94-97. Paris: CNRS.

Desjarlais, Robert R. 2003. Sensory Biographies: Lives and Deaths among Nepal's Yolmo Buddhists. Berkeley/Los Angeles/London: University of California Press.

Diemberger, Hildegard. 1997. "Beyul Khenbalung, the Hidden Valley of the Artemisia: On Himalayan Communities and their Sacred Landscape." In Mandala and Landscape, edited by Alexander W. MacDonald, 287-334. New Delhi: DK Printworld.

Dollfus, Pascale. 2003. “De quelques histoires de klu et de btsan." Revue d’Études Tibétaines 2:4-39.

Dondrup, Khenpo Nyima. 2010. Guide to the Hidden Land of the Yolmo Snow Enclosure and its History. Kathmandu: Vajra Publications.

Dowman, Keith. 1973. The Legend of the Great Stupa. Berkeley: Dharma.

Dumont, Louis. 1980. "Postface: Toward a theory of hierarchy." In Homo Hierarchicus: The Caste System and its Implications, 239-46. Chicago: University of Chicago Press.

Eck, Kristine. 2010. “Recruiting Rebels: Indoctrination and Political Education in Nepal.” In The Maoist insurgency in Nepal: Revolution in the Twenty-First Century, edited by Mahendra Lawoti and Anup K. Pahari, 33-51. London/New York: Routledge.

Ehrhard, Franz-Karl. 1990. "The Stūpa of Bodhnāth: A Preliminary Analysis of the Written Sources." Ancient Nepal. Journal of the Department of Archaeology 120:1-9.

Ehrhard, Franz-Karl.1991. "Further Renovations of the Svayambhūnāth Stūpa (from the $13^{\text {th }}$ to the $17^{\text {th }}$ Centuries)." Ancient Nepal. Journal of the Department of Archaeology 123-125: 10-20.

Ehrhard, Franz-Karl. 1994. "The Role of 'Treasure Discoverers' and their Writings in the Search for Himalayan Sacred Lands." The Tibet Journal 19.3:2-20.

Ehrhard, Franz-Karl.2013a. Buddhism in Tibet and the Himalayas. Texts and Traditions. Kathmandu: Vajra Publications. 
Ehrhard, Franz-Karl. 2013b. “A Forgotten Incarnation Lineage: the Yol-mo-ba sprul-skus

(16th to 18th centuries)." In Buddhism in Tibet and the Himalayas: Texts and Traditions, edited by Franz-Karl Ehrhard, 121-150. Kathmandu: Vajra Publications.

Ehrhard, Franz-Karl. 2013c. "Concepts of Religious Space in Southern Mustang: the Foundation of the Monastery sKu-Tshab gter-Inga." In Buddhism in Tibet and the Himalayas: Texts and Traditions, edited by Franz-Karl Ehrhard, 218-228. Kathmandu: Vajra Publications.

Ehrhard, Franz-Karl. 2013d. "A 'Hidden Land' in the Tibetan-Nepalese Borderlands." In Buddhism in Tibet and the Himalayas: Texts and Traditions, edited by Franz-Karl Ehrhard, 259-282. Kathmandu: Vajra Publications.

Gardner, Alexander. 2006. "The Sa Chog. Violence and Veneration in a Tibetan Soil Ritual." Études mongoles et sibériennes, centrasiatiques et tibétaines 36-37:283-323.

Gellner, David N., Joanna Pfaff-Czarnecka, and John Whelpton, eds. 2008. Nationalism and Ethnicity in Nepal. Kathmandu: Vajra Publications.

Gellner, David N., Sondra Hausner, and Chiara Letizia, eds. 2016. Religion, Secularism and Ethnicity in Contemporary Nepal. New Delhi: Oxford University Press.

Goldstein, Melvyin C. 1975. "Preliminary Notes on Marriage and Kinship." Contributions to Nepalese Studies 2.1:57-69.

Gyaltsen, Sherab, and Lama Dawa, eds. 1983. Collected Biographies and Prophecies of the Byang Gter Tradition: Reproduced from MS. From the Library of Bla-ma Sengge of Yol-mo. Gangtok: Palace Monastery.

Höfer, Andras. 1979. The Caste Hierarchy and the State in Nepal. A Study of the Muluki Ain of 1854. Innsbruck: Universitätsverlag Wagner.

Huber, Toni, ed. 1999. Sacred Spaces and Powerful Places in Tibetan culture: a collection of essays. Dharamsala: LTWA.

Huber, Toni, and Stuart Blackburn. 2012. Origins and Migrations in the Extended Eastern Himalayas. Leiden/Boston: Brill.

Hutt, Michael, ed. 2004. Himalayan People's War: Nepal's Maoist rebellion. Bloomington and Indianapolis: Indiana University Press.

Lawoti, Mahendra, and Anup K. Pahari, eds. 2010. The Maoist Insurgency in Nepal: Revolution in the Twenty-First Century. Routledge Contemporary South Asia Series, 20. London: Routledge.

Lawoti, Mahendra, and Susan Hangen, eds. 2013. Nationalism and Ethnic Conflict in Nepal: Identities and Mobilization after 1990. Vol. 58. London/New York: Routledge.

Lecomte-Tilouine, Marie, ed. 2013. Revolution in Nepal: An Anthropological and Historical Approach to the People's War. New Delhi and Oxford: Oxford University Press.

Levine, Nancy E. 1987. "Caste, State, and Ethnic Boundaries in Nepal." The Journal of Asian Studies 46.1:71-88.

MacDonald Alexander W., ed. 1997. Mandala and Landscape. New Delhi: DK Printworld Mumford, Stan Royal. 1989. Himalayan Dialogue: Tibetan lamas and Gurung shamans in Nepal. Madison: University of Wisconsin Press.

Pommaret-Imaeda, Francoise. 2003, "Êtres soumis, Êtres protecteurs: Padmasambhava et les Huit Catégories de Dieux et Démons au Bhouthan." Revue d'Études Tibétaines 2:40-66.

Pradhan, Rajendra. 2011. "Ethnicity, Caste and a Pluralist Society." In Perspectives on Modern South Asia: A Reader in Culture, History, and Representation, edited by Wiswesaran Kamala, 100-111. Malden: Wiley-Blackwell. 
Quintman, Andrew. 2008. “Toward a Geographic Biography: Milarepa's Life in the Tibetan Landscape." Numen 55.4: 363-410.

Quintman, Andrew. 2014. “Redacting Sacred Landscape in Nepal: The Vicissitudes of Yolmo's Tiger Cave Lion Fortress." In Highland Passages: Himalayan Studies in Honor of Hubert Decleer, edited by Benjamin Bogin and Andrew Quintman, 69-95. Boston: Wisdom Publications.

Raeper, William, and Martin Hoftun. 1992. Spring Awakening: An Account of the 1990 Revolution in Nepal. New Delhi: Viking.

Ramble, Charles. 1997. "Tibetan Pride of Place: or, why Nepal's Bhotiyas are not an Ethnic Group." In Nationalism and Ethnicity in a Hindu Kingdom, edited by David N Gellner, Joanna Pfaff-Czarnecka, and John Whelpton, 379-413. Studies in Anthropology and History, 20. Amsterdam: Harwood Academic Publishers.

Ramble, Charles. 1999. "The politics of sacred space in Bon and Tibetan popular tradition." In Sacred Spaces and Powerful Places in Tibetan Culture: a Collection of Essays, edited by Toni Huber, 3-33. Dharamsala: LTWA.

Rodseth, Lars. 2005. "The Fragmentary Frontier: Expansion and Ethnogenesis in the Himalayas." In Untaming the Frontier in Anthropology, Archaeology, and History, edited by Bradley J. Parker and Lars Rodseth, 100-109. Tucson: University of Arizona Press.

Ruegg, David Seyfort. 2008. The Symbiosis of Buddhism with Brahmanism/Hinduism in South Asia and of Buddhism with "Local Cults" in Tibet and the Himalayas. Wien: Austrian Academy of Sciences.

Samuel, Geoffrey. 1993. Civilized Shamans. Buddhism in Tibetan Societies. Washington: Smithsonian Institution Press.

Samuel, Geoffrey. 2013. "Revisiting the Problem of Bon Identity: Bon Priests and Ritual Practitioners in the Himalayas." Journal of the International Association for Bon Research 1, Inaugural Issue: 78-97.

Schrempf, Mona. 1994. "Tibetan Ritual Dances and the Transformation of Space." The Tibet Journal 19.2:95-120.

Scott, James C. 2009. The Art of Not Being Governed: An Anarchist History of Upland Southeast Asia. New Haven: Yale University Press.

Shneiderman, Sara. 2006. "Barbarians at the Border and Civilising Projects: Analysing Ethnic and National Identities in the Tibetan Context." In Tibetan Borderlands, edited by P. Christiaan Klieger, 9-34. Leiden: Brill.

Shneiderman, Sara. 2010. "Are the Central Himalayas in Zomia? Some scholarly and political considerations across time and space." Journal of Global History 5.2 :289-312.

Srinivas, Mysore Narasimhachar. 1952. Religion and Society among the Coorgs of South India. Oxford: Clarendon Press.

Steinmann, Brigitte. 2003. "Les Lha srin sde brgyad et le problème de leur catégorisation Une interprétation.” Revue d'Études Tibétaines 2:81-91.

Torri, Davide. 2015. "The Animated Landscape: Human and Non-Human Communities in the Buddhist Himalayas." In "Proceedings of the International Conference 'The human person and nature in classical and modern India'," edited by Raffaele Torella and Giorgio Milanetti, Supplement, Rivista di Studi Orientali 88.2: 251-268.

Van Schendel, William. 2002. "Geographies of knowing, geographies of ignorance: jumping scale in Southeast Asia." Environment and Planning D 20.6:647-668. 
